\section{International Journal of Karamanoglu Mehmetbey Educational Research}

ULUSLARARASI

KARAMANOĞLU MEHMETBEY EĞITIMM ARASTIRMALARI DERGISİ

Cilt 3 - Özel Sayı 1 Eylül 2021

\title{
Radyo Tiyatrosunun Dinlediğini Anlama Becerisine Etkisi
}

\section{The Effect of Radio Theater on Listening Comprehension}

Esra Nur Tiryaki*1 $^{*}$ Semra Kolcu Canatar ${ }^{2}$

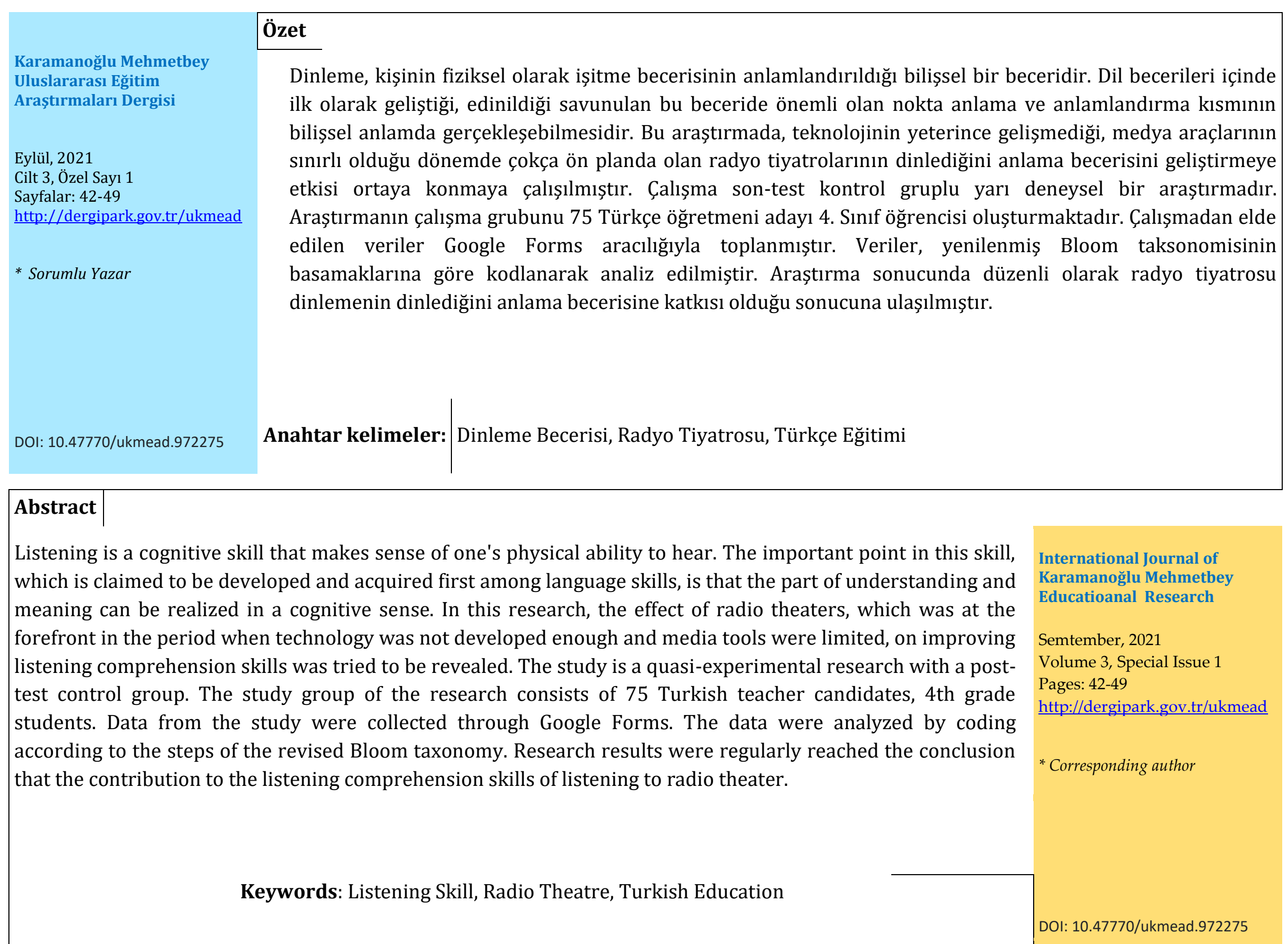

${ }_{1}^{1}$ Assoc. Prof. Dr. Hatay Mustafa Kemal University, Education Faculty, etiryaki@,mku.edu.tr.

2 Phd Student, Hatay Mustafa Kemal University, Social Sicences Institutw, s.kolcu24@gmail.com 


\section{GíRiş}

Dinleme, işitmenin mekanik olarak zihinde algılanması ve anlamlandırılmasıdır. Karabay, (2010) dinleme sürecini, "bireyin seslerin ve konuşma örüntülerinin farkında olmasıyla ve bunlara dikkat etmesiyle başlar; belli işaretleri tanıması ve hatırlamasıyla sürer ve anlamlandırmasıyla son bulur” şeklinde tanımlamıştır. Alıcı dil becerisi olan dinleme, diğer becerilerin gelişmesine zemin hazırlar. Dilin prozodik unsurlarla örülü ahenkli yapısı kişide dinleme ile gelişir. Bu beceri, pasif bir süreç olarak algılanmış olsa da günümüzde, konuşmacı tarafından söylenen seslerin tanınması, bilgi odağını gösteren tonlama kalıplarının algılanması, bahsedilenin ilgi düzeyinin yorumlanması (Lynch ve Mendelsohn, 2013) gibi anlama süreçlerini de içerdiğinden etkin bir yorumlama ve işitilenlerin zihinde yapılandırılması olarak tanımlanmaktadır. Dil becerilerinin edinimi ile ilgili yapılan çalışmalar, iletişim kurulduğunda dil yeterliliğinin \%45'inin dinlemeden, \%30'unun konuşmadan, \%15'inin okumadan ve \%10'unun yazmadan kazanıldığını kanıtlamıştır (Renukadevi, 2014).

Dinleme, tüm dil becerileri gibi eğitimle geliştirilebilen bir beceridir. Temel düzeyde, duyulanı genel olarak anlamlandırmak akademik dinleme için yeterli değildir. Dinleyenin, cümleleri konuşanın aktarmak istediği şekilde kullanması için üç çeşit bilgiyi kodlaması gerekir; konuşma edimi, önerme içeriği ve konu içeriği (Schunk, 2014). Dinlediğini anlama ve daha da önemlisi, dinlenenin bilinç süzgecinden geçirilerek bilgi düzeyinde ve yerinde kullanma becerisinin geliştirilmesi dinleme eğitiminin gerekliliğine dair sebeplerden sadece birkaçıdır. Dinleme, basit bir eylem değildir. Dinlemenin neden zor olduğunu gösteren kanıtlar başlıca dört kaynaktan gelmektedir; dinlenecek mesaj, konuşmacı, dinleyici ve fiziksel ortam (Yagang, 1993). Bu kaynakların aynı anda uygun düzeyde bulunmasının ne derece zor olduğunu günlük hayatta da fark etmek mümkündür. Sıradan bir sohbet esnasında bile konuşmacılar konuyu sık sık değiştirir, dinleyicinin dikkati dağılır ve içerik genellikle iyi organize edilmemiştir. Konuşmacıdan, söyleneni sürekli tekrar etmesini istemek mümkün değildir. Bu açıdan bakıldığında en basit haliyle de dinleme özen ve dikkat gerektiren bir anlama sürecidir. Dinleme sürecindeki unsurlar "algılama, dikkati yoğunlaştırma, anlamlandırma ve hatırlama (cevaplama)” dır (Kingen, 2000'den akt. Doğan, 2007,):

- Algılama: Sesli uyaranları ve sözsüz iletişim sinyallerini fark etme.

- Dikkati Yoğunlaştırma: Dinlenilen şeye odaklanma.

- Anlamlandırma: Duyulan sesli uyaranı anlama ve yorumlama.

- Hatırlama (Cevaplama): Tepki verebilmek için sesli uyaranı bellekte saklama.

Yukarıdaki unsurları yerine getirebilen bir kişi dinlediğini anlama konusunda başarılı sayılabilir. Dinleme konusunda birçok sınıflandırma yapılabilir: stratejiye dayalı, estetik, eleştirel, bilgi amaçlı, katılımll, empatik, yaratıcl, pasif dinleme bunlardan bazılarıdır. En basit haliyle dinleme becerisini sınıflandıran Harmer da (2001) işlevsel ve keyfi dinleme olmak üzere iki tür dinlemeden bahsetmektedir. Eğitim sürecinde dinleme çeşitlerinden dönüşümlü olarak faydalanılmaktadır. Bir konuşmacıyı, radyoyu veya ses içeren bir videoyu dinlemek ve onu anlamlandırmak; belirli bir zaman zarfı içerisinde aktarılan sözcükleri anlayacak düzeyde sözcük bilgisine sahip olmak, konuyla ilgili ön bilgileri gün yüzüne çıkararak yeni bilgilerle ilişkilendirmek, ilgili noktaları belirlemek, konuşmanın devamıyla ilgili tahminde bulunmak veya söyleneni kendi düşünceleriyle karşılaştırmak gibi dizgeli bir dizi zihinsel işlemin yapılmasını gerektirdiğinden dinleme becerisinin gelişmiş olmasını zorunlu kılar. Bu nedenle, dinleme, öğrenme sürecinin önemli bir parçası olduğundan, öğretmenler ders işleme sürecinde öğrencilerinin öğrenme stillerini de göz önünde bulundurarak, etkili dinlemeyi ortaya çıkarmak için (Beall, Rosier, Tate ve Matten, 2008) dinleme türlerinden uygun olana başvurur. Nihai noktada dinleme eğitiminin, türü fark etmeksizin tüm dinleme çeşitlerinde kişide anlamayı güçlendirmesi temel amacıdır.

Dinleme eğitimi Türkçe öğretiminde dil becerilerinin öğretiminde zemini oluşturur. Bu zemin üzerine okuma, yazma ve konuşma becerileri gelişir. Buna ek olarak Türkçe öğretiminin temel hedeflerinden biri; "öğrencilerin hayat boyu kullanabilecekleri dinleme/izleme, konuşma, okuma ve yazma ile ilgili dil becerilerini ve zihinsel becerileri kazanmaları, bu becerileri kullanarak kendilerini bireysel ve sosyal yönden geliştirmeleri ve etkili iletişim kurmalarını sağlamaktır" (MEB, 2019, s. 8-9). Ders esnasında öğretmenler, hazırlıksız konuşma yaparken veya herhangi bir konuyu anlatırken mesajını iletmek için gerekenden çok daha fazlasını söylerler, bu fazlalık konuşmanın doğal bir özelliğidir (Yagang, 1993, s. 18). Dil becerileri kazandırma hususunda kendini geliştirmiş öğretmenler, ders saati ile sınılı olan öğretme sürecinde, fikirleri defalarca tekrarlayarak zamanı boşa harcamak yerine öğrencilere etkili dinleme yeteneğini kazandırabilir (Beall, Rosier, Tate ve Matten, 2008). Bu nedenle, öğretmenlerin öğrencilerinden etkili dinleme elde etme yeteneği ve Türkçe öğretmeni adaylarının buna yönelik nitelikli bir dinlediğini anlama becerisine sahip olması önem taşımaktadır.

Dil becerilerinin öğretiminde izlenecek tekniklerin Türkçe öğretmeni tarafından doğru biçimde seçilip uygulanması önemlidir. Öğrencilerin seviyelerine, ilgi ve yeteneklerine çeşitli yöntemler kullanılabilir. Öğrenme sürecinde öğrencinin aktif olması açısından farklı dinleme türleri anlatılmalı ve dinleme eğitimi esnasında yapılan etkinlikler, öğrencinin ilgisini çekmeli, öğrenciyi istekli hale getirmelidir (Yıldız ve Savaş, 2019). Bu sebeple, yapılan bu araştırmada, farklı ve ilgi çekici bir yöntem olarak radyo tiyatrolarının dinleme becerisini geliştirmedeki etkisi ele alınacaktır.

Dinlediğini anlamanın temel hedef olduğu dinleme eğitimi, Türkçe derslerinde metinler aracılığı ile verilir. Bu metinlerin türlerine bakıldığında da okuma veya dinleme için var oldukları görülür. Metin türleri içerisinde yer alan tiyatro ise olayları oluş açısından göstermesi yönüyle konuşmaya, eyleme dayanan bir sahne sanatı olarak diğer türlerden ayrılır. Temeli milattan önceye dayanan bir tür olan tiyatro, hayal gücünün çok daha ötesine taşınabilen bir sanattır. Tiyatro eğitim alanında temel dil 
becerilerinin geliştirilmesi ve hedef kazanımların gerçekleşmesi için kullanılmakla birlikte öğrencilerin hayata karşı bakıș açılarını değiştirmek, dünyaya farklı açılardan bakabilmelerini sağlamak için de kullanılmaktadır (Altunbay, 2012). Tiyatro ilk zamanlarda uzunca bir süre sadece sahne sanatı olarak devam etse de zamanla okuma tiyatroları da dinleyici kitlesine hitap etmeye başlamıştır. Okuma tiyatrolarında dekora, kostüme, sahnede devinime gerek yoktur. Tiyatro, okuma tiyatrosu ve radyo tiyatrosu kavramları birbirinden farklıdır ancak bu ayrım kavramların farklı edebi türler olduğunu göstermez; aralarındaki fark sunuş biçimiyle ilgilidir. Dramatize programlar, radyo program türlerinden biridir. Bazen bütün bir program bazen de bir programın çeşitli bölümleri oyunlaştırılarak sunulur. Bütün bir programın oyunlaştırılarak sunulmasına "Radyo'da Tiyatro" ya da "Radyo Oyunu" adı verilir (Kars, 1993).

Türkiye'de radyo yayıncılığı 1927 yılında başlamıştır. Diğer ülkelerle kıyaslandığında bu tarihin çok da geç bir tarih olmadığı söylenebilir (Cankaya, 2011). Radyo yayınları ilk zamanlarda sadece canlı yapılabilmekteyken zamanla gelişme göstermiş, bant yayınları da kullanılmaya başlanmıştır. Canlı yayın esnasında radyo tiyatrolarının sunumu zor olduğundan teknolojinin, radyo yayınlarının gelişimiyle birlikte radyo tiyatrolarının sunumu da kolaylık kazanmıștır.

Dünyada radyo tiyatrosunun kullanımı ise ülkemizden öncedir. İlk özgül radyo tiyatrosu, Britanya'da 15 Ocak 1924'te sunulan ve bilinçli olarak radyo formatının potansiyelini kullanan Richard Hughes'ın A Comedy of Danger adlı oyunudur (Hand ve Traynor, 2011). Radyo tiyatrosunun ilk örnekleri Türkiye'de 1950'lerde İstanbul Radyosunda yayımlanmıștır, 1970'li yıllara gelindiğinde ise Radyo Tiyatrosu ve Arkası Yarın gibi programlar yapılmıştır (Cankaya, 2011). Radyo ve tiyatronun bir araya getirildiği ve televizyonun yaygın olmadığı dönemlerde ilgiyle ve zevkle dinlenen radyo tiyatroları olaylara farklı açılardan bakarak hayal gücünü geliştirirken estetik algıyı pekiștirerek sanata olan ilgiyi arttırır. "Radyo ve televizyon programlarının, tiyatroların, konferansların, konserlerin dinlenmesi ve seyredilmesi çağımız insanının vazgeçemeyeceği gereksinimleri arasındadır" (Özbay, 2001). Televizyon ve internet kullanımı günümüzde radyonun önüne geçse de çeşitli dinleme türlerine hitap eden radyo tiyatrosu formatı varlığını sürdürmektedir. "Ana dili ve yabancı dili öğreniminde bir tiyatro eseri dinleyenlerde kelimelerin vurgusundan tonlamalarına, telaffuzdan sesin kullanımına kadar birçok unsurun doğru algılanmasına katkıda bulunur. Bu nedenle dil öğreniminde hedef kitlenin seviyesine uygun olarak düzenli aralıklarla çeşitli konularda tiyatro izlenmesi dinleme becerisinin gelişimine katkıda bulunmakla beraber öğrenmeyi de hızlandıracaktır" (Altunbay, 2012).

Dinlediğini anlama becerilerinin gelişiminde radyo tiyatrolarının etkisini ortaya koymaya çalışan bu çalışmada, anlama ve bilimsel sorgulama becerilerinin ortaya konmasını sağlayan var olan stratejiler içerisinde genel olarak kabul gören Bloom'un bilişsel alan taksonomisi kullanılmıștır. "Bilişsel becerileri ölçebilecek soruların sınıflandırılmasında ve eğitim-öğretim hedeflerinin belirlenmesinde en çok tercih edilen sınıflandırma Bloom'a ait taksonomidir" (Aktaş, 2017). 1956 yllından bu yana önemini yitirmeden kullanılan ve ölçme-değerlendirme süreçlerinde tüm dünyada kabul gören taksonomi, öğrenmenin gerçekleşme sürecine dair yeni felsefelerin ortaya çıkması, analiz ve değerlendirme basamaklarına ilişkin tam bir anlaşmanın sağlanamaması, öğrenmede bireyselliğin ve tüm öğrenme sürecinin açıklanmasında yetersiz kaldığı (Tutkun, 2012) dolayısıyla taksonominin güncel eğitim yaklaşımlarına uyum sağlaması gerektiği sebepleriyle yenilenmiştir. Bloom taksonomisi temelde düşünme süreçlerinin bir düzen içerisinde sıralanarak ayrıldığı bir sınıflandırmadır. Yenilenmiş Bloom taksonomisi sırasıyla hatırlama, anlama, uygulama, analiz etme, değerlendirme ve en üst düzey olarak da yaratma basamağından oluşmaktadır. Sınıflamada olgusal, kavramsal, işlemsel ve üstbilişsel olarak toplamda dört alt içeriğe sahip olan bilgi boyutu ve kazanımların eylem boyutunu ifade eden bilişsel süreç boyutu ile birlikte farklı iki boyut ortaya konmaktadır (Tutkun ve Okay, 2012). Taksonominin her basamağı bir üst basamağa geçişin temelini oluşturmaktadır. Yenilenmiş Bloom taksonomisinde anlama, hatırlama ve uygulama basamakları alt seviye; değerlendirme, analiz ve yaratma basamakları üst seviye düşünme becerilerine karşılık gelmektedir. Bu sebeple, radyo tiyatrolarının dinlediğini anlamaya etkisininin ortaya konmaya çalışıldığı bu çalışmada, dinlediğini anlama sürecinin belirlenmesinde yenilenmiş Bloom taksonomisi kullanılmıştır.

\section{Araștırmanın Amacı}

$\mathrm{Bu}$ araştırmanın amacı, Türkçe öğretmen adaylarının radyo tiyatrosu kullanımının dinlediğini anlama becerisine etkisini belirlemektir. Araştırma, dinleme eğitiminde farklı kaynaklar kullanmanın sonuçlarını göstermesi açısından önemlidir. Yenilenmiş Bloom taksonomisine göre Türkçe öğretmeni adaylarında dinlediğini anlama becerisindeki değişim ortaya konmaya çalışılmıştır.

\section{YÖNTEM}

Bu bölümde araștırmanın modeli, çalışma grubu, veri toplama araçları ve elde edilen verilerin analizine yer verilmiştir.

\section{Araştırmanın Modeli}

Bu araştırmada yarı deneysel desen kullanılmıștır. Yarı deney, bir müdahalenin kullanımını kapsar ancak katılımcıların gruplara seçkisiz atanması söz konusu değildir (Cresswell, 2019). Bu yöntemin tercih edilme sebebi okullarda deney ve kontrol gruplarının kontrol değişkenleri açısından eşitlenmesinin zorluğudur. Bundan dolayı birbirine benzer nitelikteki mevcut iki sınıftan biri kontrol diğeri deney grubu olarak kullanılmış ve gruplar tesadüfî şekilde seçilmiştir. 
Araştırmanın çalışma grubunu, 2018-2019 güz yarıyılında Hatay Mustafa Kemal Üniversitesi Eğitim Fakültesi Türkçe Öğretmenliği Bölümü 4. sınıfında öğrenim gören 75 Türkçe öğretmeni adayı oluşturmaktadır. Bu araştırmada öncelikle deney (1. grup) ve kontrol (2. grup) grupları rastlantısal olarak belirlenmiștir.

\section{Veri Toplama Araçları}

Bu araștırma da veriler, Google forms aracılı̆̆ıyla "Radyo Tiyatrosu Dinlediğini Anlama" formu tarafından toplanmıștır. Türkçe öğretmeni adaylarına uygulanan dinlediğini anlama testinin soruları yenilenmiş Bloom taksonomisi baz alınarak hazırlanmıştır. Öncelikle, toplamda iki radyo tiyatrosunun (Acımak ve Bir Eskimo Kızının Romanı) içeriğine yönelik, taksonominin her bir basamağına ait 6 soru olmak üzere toplamda 36 soru olușturulmuștur. Hazırlanan sorular, radyo tiyatrosu metinleriyle birlikte uzman görüşüne sunulmuştur. Uzmanların görüşleri doğrultusunda 36 soru içerisinden 12 çoktan seçmeli soru seçilmiş ve uzmanların dönütlerine dayanarak gerekli düzenlemeler yapılmıştır. Bu durum ölçme aracının kapsam geçerliliğini sağlama açısından yeterli bulunmuştur.

Çalışmaya katılan öğrencilerden etik kurallarına uygun olarak gönüllülük beyanı alınmıştır. Katılımcılar yapılan çalışmanın amacını bilerek kendi rızaları ile araştırmaya dâhil olmuşlardır. Dinlediğini anlama testi öncesinde katılımcılara sunulan gönüllülük beyanı örneği aşağıda sunulmuştur.

(Sizden toplanan yanıtlar bilimsel bir çalışmada kullanılacak ve sizin yazılı izniniz olmadan başkalarıyla paylaşılmayacaktır. Çalışma sırasında herhangi bir rahatsızlık hissederseniz çalışmadan istediğiniz zaman ayrılabilirsiniz.) Bu çalışmaya tamamen kendi rızamla, istediğim takdirde çalışmadan ayrılabileceğimi bilerek katılıyor ve verdiğim bilgilerin bilimsel amaçlarla kullanılmasını kabul ediyorum.

Araştırmada yalnızca deney grubuna eğitim-öğretim yarıyılı içerisinde, haftada 1, toplamda 10 adet radyo tiyatrosu dinletilmiştir. Her bir radyo tiyatrosu için 1 ders saati süre ayrılmıştır. 10 hafta süresince 2. gruba hiç radyo tiyatrosu dinletilmemiştir. Radyo tiyatroları arasından daha önce 1. gruba hiç dinletilmeyen "Acımak" ve "Bir Eskimo Kızının Romanı" isimli iki okuma tiyatrosu seçilmiş ve her iki gruba da 10 haftalık süre sonunda bu radyo tiyatroları ilk kez dinletilmiştir. Adaylardan, yenilenmiş Bloom taksonomisi esas alınarak hazırlanan ve taksonominin her basamağı için 1 soru olmak üzere, 2 metin için toplam 12 çoktan seçmeli dinlediğini anlama sorusunu cevaplamaları istenmiştir. Kodlayıcılar arası uyum yapılarak cevap anahtarı hazırlanıp güvenilirlik sağlanmıștır.

\section{Verilerin Analizi}

Araştırmada Türkçe öğretmeni adaylarının sorulara verdikleri yanıtlar betimsel istatistiki teknikler(f ve \%) kullanılarak analiz edilmiştir. Hatırlama ve anlama basamağına ait sorulara verilen doğru yanıtların her biri 5'er puan, uygulama, analiz etme, değerlendirme ve yaratma basamağına ait sorulara verilen doğru yanitlar ise 10'ar puan değerindedir. Bu durumda tüm sorulara doğru cevap veren Türkçe öğretmeni adayı en yüksek 100 puan alacaktır. 0-100 puan aralığı 3'e bölünmüş ve $0 \leq \mathrm{x} \leq$ 55 alanlar zayıf, $56 \leq \mathrm{x} \leq 79$ arası puan alanlar orta ve $80 \leq \mathrm{x} \leq 100$ aralığında puan alanlar başarılı kabul edilmiştir. Verilerin elde edilmesinde yenilenmiş Bloom taksonomisinin basamaklarına göre hazırlanmıș dinlediğini anlama testi kullanıldığından, sunulan ilk 6 tablo taksonominin her bir basamağına ait sorulara verilen cevapların analizini içermektedir. Taksonomi basamaklarına göre yapılan incelemelere ait tablolarda frekans değerleri öğrenci sayısını değil soruya verilen yanıt sayısını göstermektedir. Çünkü her basamağa ait ikişer soru bulunmaktadır. 1. Grupta 38, 2. grupta 37 öğrenci ve her basamakta 2 soru olduğundan öğrenciler her basamakta kişi başı 2 soruya cevap vermiştir ve dolayısıyla toplam frekans değeri öğrenci sayısının iki katı olacak şekilde; her bir basamakta 1 . grup için 76, 2. grup için 74'tür.

\section{BULGULAR}

Bu bölümde, araștırmadan elde edilen veriler tablolar halinde sunularak ortaya konmuş ve yorumlanmıștır. Araștırmadan elde edilen bulgular şu şekildedir:

Tablo 1.

Hatırlama Basamağına Ait Bulgular

\begin{tabular}{lllll}
\hline & \multicolumn{2}{l}{ 1.Grup } & & 2.Grup \\
\cline { 2 - 5 } & $\mathrm{f}$ & $\%$ & $\mathrm{f}$ & $\%$ \\
\hline Doğru & 75 & 98,7 & 65 & 87,9 \\
Yanlış & 1 & 1,3 & 9 & 12,1 \\
Toplam & 76 & 100 & 74 & 100 \\
\hline
\end{tabular}


Tablo 1'e bakıldığında 1. grupta (deney grubunda) yer alan 38 Türkçe öğretmeni adayının toplamda verdiği 76 yanıttan sadece f=1'i yanlıştır. Aynı iki soruya 2. grupta yer alan 37 Türkçe öğretmeni adayının verdiği 74 yanıttın f=9'u yanlıştır. Daha önce dinlediğini anlama becerisini geliştirmeye yönelik radyo tiyatrosu dinletilen 1. grubun hatırlama basamağına ait sorulara verdiği cevapların doğruluğu 2. gruba göre \% 10,8 daha yüksektir.

Tablo 2.

Anlama Basamağına Ait Bulgular

\begin{tabular}{|c|c|c|c|c|}
\hline & \multicolumn{2}{|c|}{ 1.Grup } & \multicolumn{2}{|c|}{ 2.Grup } \\
\hline & $\mathrm{f}$ & $\%$ & $\mathrm{f}$ & $\%$ \\
\hline Doğru & 72 & 94,8 & 60 & 81,1 \\
\hline $\begin{array}{l}\text { Yanlış } \\
\text { Toplam }\end{array}$ & $\begin{array}{l}4 \\
76 \\
\end{array}$ & $\begin{array}{l}5,2 \\
100\end{array}$ & $\begin{array}{l}14 \\
74\end{array}$ & $\begin{array}{l}18,9 \\
100\end{array}$ \\
\hline
\end{tabular}

Anlama basamağına ait bulgulara bakıldığında 1 . gruptan toplamda $\mathrm{f}=4$ yanlış 2 . gruptan ise f=14 yanlış cevap çıktı̆̆ı görülmektedir. Arada 10 cevaplık fark oluştuğu açıktır. 1. grubun başarı oranı \%94,8 iken 2. grubun başarı oranı \%81,1'dir.

Tablo 3.

Uygulama Basamağına Ait Bulgular

\begin{tabular}{|c|c|c|c|c|}
\hline & \multicolumn{2}{|c|}{ 1.Grup } & \multicolumn{2}{|c|}{ 2.Grup } \\
\hline & $f$ & $\%$ & $\mathrm{f}$ & $\%$ \\
\hline Doğru & 72 & 94,8 & 55 & 74,4 \\
\hline Yanlış & 4 & 5,2 & 19 & 25,6 \\
\hline Toplam & 76 & 100 & 74 & 100 \\
\hline
\end{tabular}

Tablo 3'e göre 1. ve 2. grubun sorulara verdiği doğru cevap sayıları arasındaki fark 18'dir. 1. grubun başarı oranı \%94,8, 2. grubun ise \%74,4'tür. İki grubun başarı yüzdesi arasındaki farkın, ilerleyen her basamakta daha da arttı̆̆ görülmektedir. Bir önceki basamak olan anlama basamağında iki grup arasındaki fark \%13,7 iken uygulama basamağında bu fark \%20,4'e çıkmıştır.

Tablo 4.

Analiz Etme Basamağına Ait Bulgular

\begin{tabular}{lllll}
\hline & 1.Grup & \multicolumn{3}{l}{ 2.Grup } \\
\cline { 2 - 5 } & $\mathrm{f}$ & $\%$ & $\mathrm{f}$ & $\%$ \\
\hline Doğru & 70 & 92,2 & 52 & 70,3 \\
Yanlış & 6 & 7,8 & 22 & 29,7 \\
Toplam & 76 & 100 & 74 & 100 \\
\hline
\end{tabular}

Tablo 4'teki veriler incelendiğinde 1 . grubun bu basamağa ait sorulara toplamda f=70 doğru cevap verdiği, buna karşın 2 . grupta bu sayının f=52'de kaldığı görülmektedir. Grupların sorulara verdiği yanlış cevap sayılarına bakıldığında 1. grup f=6; 2 . grup ise $\mathrm{f}=22$ yanlış cevap vermiştir. Tablo 4'te yer alan veriler ile Tablo 3 'te yer alan veriler karşılaştırıldığında 1. grubun her iki basamakta da doğru ve yanlış sayılarında büyük bir fark oluşmaz iken 2. grupta yer alan öğretmen adaylarının uygulama basamağında f=19 olan yanlış cevap sayısının analiz etme basamağında f=22'ye çıktığı görülmektedir.

Tablo 5.

Değerlendirme Basamağına Ait Bulgular

\begin{tabular}{lllll}
\hline & \multicolumn{3}{l}{ 1.Grup } & \multicolumn{3}{l}{ 2.Grup } \\
\cline { 2 - 5 } & $\mathrm{f}$ & $\%$ & $\mathrm{f}$ & $\%$ \\
\hline Doğru & 63 & 82,9 & 40 & 54,1 \\
Yanlış & 13 & 17,1 & 34 & 45,9 \\
Toplam & 76 & 100 & 74 & 100 \\
\hline
\end{tabular}

Değerlendirme basamağına ait olan Tablo 5'teki verilere bakıldığında; bu basamağa ait sorulara 1.grubun \%82,9'u doğru cevap verirken 2. Grubun \%54,1'inin doğru cevap verdiği görülmektedir. 1. gruptaki öğretmen adaylarının $\% 17,1$ 'inin; 2. gruptakilerin ise \%45,9'unun bu basamaktaki sorulara yanlış cevap verdiği anlaşılmaktadır. Bu basamakta yer alan sorulara cevap veren 2. gruptaki öğretmen adaylarının neredeyse \%50'si soruları yanlış cevaplamıștır. Ayrıca 1. grup ile 2. grup arasındaki doğru-yanlış cevap arasındaki farkın da giderek açıldığı Tablo 5 'ten anlaşılmaktadır. Tablo 4 ile Tablo 5 kıyaslandığında; her iki grupta yer alan öğretmen adaylarının sorulara doğru yanıt verme oranlarında azalma olduğu görülmektedir. 
Tablo 6.

Yaratma Basamağına Ait Bulgular

\begin{tabular}{lllll}
\hline & \multicolumn{2}{l}{ 1.Grup } & & 2.Grup \\
\cline { 2 - 5 } & $\mathrm{f}$ & $\%$ & $\mathrm{f}$ & $\%$ \\
\hline Doğru & 65 & 85,6 & 44 & 59,5 \\
Yanlış & 11 & 14,4 & 30 & 40,5 \\
Toplam & 76 & 100 & 74 & 100 \\
\hline
\end{tabular}

Tablo 6 incelendiğinde 1. grubun bu basamakta yer alan sorulara verdiği yanıtlardan f=65'inin doğru, f=11'inin yanlış; 2 grubun ise $\mathrm{f}=44$ 'ünün doğru, $\mathrm{f}=30$ 'unun yanlış olduğu görülmektedir. İki grup arasında sorulara doğru cevap verme oranları arasındaki fark \%26,1; yanlış cevap verme oranları arasındaki fark da \%26,1'dir. Bir önceki tabloya kıyasla bu tabloda her iki grupta yer alan öğretmen adaylarının doğru cevap sayılarının bir miktar arttığı söylenebilir.

Tablo 7.

Türkçe Öğretmeni Adaylarının Dinlediğini Anlama Testine Göre Başarı Dağılımları

\begin{tabular}{lcc}
\hline Başarı Durumu (Puan) & 1. Grup & 2. Grup \\
\hline Zayıf (0-55p) & N & $\mathbf{N}$ \\
Orta(56-80p) & 1 & 10 \\
Başarılı(81-100p) & 5 & 18 \\
Toplam & 32 & 9 \\
\hline
\end{tabular}

Tablo 7'de Türkçe öğretmeni adaylarının dinlediğini anlama testindeki başarı düzeyleri karşılaştırılmıştır. 10 hafta boyunca radyo tiyatrosu dinletilen 1 . grupta yalnızca 1 kişi zayıf not alırken, kontrol grubu olan 2. grupta 10 kişi zayıf not almıştır. Orta alanlar ise 1. grupta 5, 2. grupta 18 kişidir. Başarılı olan kişi sayısı ise 1. grupta 32, 2. grupta 9 kişidir. Başarılı olan öğrenci sayılarına bakıldığında 1. ve 2. grup arasında anlamlı bir fark olduğu görülmektedir.

Tablo 8.

Grupların Yenilenmiş Bloom Taksonomisine Göre Başarı Dağılımları

\begin{tabular}{lll}
\hline Basamak & 1. Grup (Başarı Oranı) & 2. Grup (Başarı Oranı) \\
\hline Hatırlama & $\% 98,7$ & $\% 87,9$ \\
Anlama & $\% 94,8$ & $\% 81,1$ \\
Uygulama & $\% 94,8$ & $\% 74,4$ \\
Analiz Etme & $\% 92,2$ & $\% 70,3$ \\
Değerlendirme & $\% 82,9$ & $\% 54,1$ \\
Yaratma & $\% 85,6$ & $\% 59,5$ \\
\hline
\end{tabular}

Tablo 8'e bakıldığında yenilenmiş Bloom taksonomisinin en alt basamă̆ı olan hatırlama basamağında, her iki grupta da başarı yüzdesi diğer basamaklara göre en yüksek orandadır. Basamaklar arttıkça başarı yüzdeleri her iki grup için de kademeli olarak düşmüştür. Ancak bu durum değerlendirme ve yaratma basamağı için geçerli değildir. Türkçe öğretmeni adaylarının taksonominin en üst basamă̆ı olan yaratma basamağındaki başarı oranları, bir alt basamak olan değerlendirme basamağından daha yüksektir. Her iki grup için de bu durum geçerlidir.

\section{TARTIŞMA, SONUÇ ve ÖNERÍLER}

Dinleme becerisi günlük hayatta ve eğitim sürecinde önemli bir yere sahip olduğundan, dinlediğini anlama hususunda güçlük yaşayan bir başka deyişle dinleme becerileri yeterince gelişmemiş bireylerin diğer becerilerde de zorluk yaşayacağı bir gerçektir. Bu nedenledir ki dinleme becerisi günlük yaşamda her bireyin, eğitim hayatında ise her öğrencinin edinmesi gereken bir beceridir. Bu beceriyi kazanmanın ve öğrencilere kazandırabilmenin yolu da planlı bir dinleme eğitiminden geçmektedir. "Öğretmen eğitiminde bireyin öğrenmeyi öğrenmesine ve üstbilişe odaklanan disiplinlerarası anlayıșı öngören, işbirliğine dayalı öğretimi işe koşan, üst düzey bilişsel süreçleri hedefleyen, yaratıcılı̆̆ı ve hayal gücünü ortaya çıkaran, teknoloji ve zengin kaynak kullanımını teşvik eden öğretim ortamlarının yaratılması gelecek nesiller için önemli ve gerekli görülmektedir" (Başbay, 2008).

Öğrenmenin gerçekleşmesi için öğrenenin dinleme sürecinde aktif olması gerekmektedir. Öğreneni ders sürecinde aktif kılmanın en önemli unsurlarından biri öğrenene yönelik dikkat geliştirme çalışmalarının yapılmasıdır. Dikkat geliştirme çalışmaları geleneksel yöntemlerle yapılabileceği gibi teknolojik unsurları işe koşarak da yapılabilir. Z kuşağının teknolojiyle olan bağı göz önünde bulundurulduğunda, çeşitli ve ilgi çekici medya unsurlarının dâhil edildiği öğrenim ortamları olumlu sonuçları beraberinde getirecektir. Sanat eğitimi ve özellikle tiyatro, çağdaș kültürümüzü yönlendirmek için gerekli olan yeni 
okuryazarlık biçimlerini kabul edip keşfeden öğretmenler ve öğrenciler arasındaki etkileşimlere önemli ölçüde katkıda bulunmak için benzersiz bir konuma sahiptir (Jensen, 2008). Bu bağlamda dinleme eğitiminde ve dikkat geliştirme sürecinde sanatsal ve ilgi çekici bir etkinlik olarak radyo tiyatrolarının kullanılmasının yapılan bu araştırma sonuçlarına göre faydalı olacağı görülmektedir. Göçer ve Kurt (2020) da " radyo oyunları, temeli tiyatral faaliyete dayanan bir sanattır. İçinde ses, efekt, müzik, diyalog gibi sözlü iletişimde kullanılan unsurları diri tutan bir yapıya hakimdir” diyerek bu görüşü desteklemektedir. Bu araştırmada, Türkçe öğretmeni adaylarının radyo tiyatrosu kullanımının dinlediğini anlamaya etkisi ortaya konmaya çalışılmıştır. Bu araştırmanın sonucunda, genel başarı ortalaması 1. ve 2. gruplarda oldukça farklıdır. 1. grupta testin sonucunda başarısız olan kişi sayısı 1 iken 2. grupta bu sayı 10'dur. Başarılı olan kişi sayısı ise 1. grupta 32, 2. grupta 9'dur. Deney ve kontrol grupları arasında dinlediğini anlama açısından fark görülmüştür. Tüm basamaklarda ve testin genel sonucunda 1. grup dinlediğini anlama konusunda 2. gruptan daha başarılı sonuçlar ortaya koymuştur. Hatırlama, anlama ve uygulama basamağında iki grup arasında yaklaşık \%10'luk bir fark varken; analiz etme, değerlendirme ve yaratma basamağında 1 . grup 2. gruptan ortalama \%20 daha fazla başarı elde etmiştir. Yenilenmiş Bloom taksonomisinin basamaklarına göre hazırlanmış test ile ölçme ve değerlendirmenin yapıldığı bu araştırmada her basamakta bir öncekine göre her iki grupta da başarı yüzdesinde düşüş olduğu görülmüştür. Dinleneni anlama sürecinde bilgiyi işleme boyutu soyutlaştıkça öğrencilerin dinlediğini anlama testindeki başarı yüzdesinde sistematik bir düşüş gözlenmiştir. Fakat bu durum değerlendirme ve yaratma basamağı için geçerli değildir. 1. grup değerlendirme basamağında \%82,9 başarı oranına sahipken yine aynı grup yaratma basamağında \%85,6'lık bir başarı oranı ortaya koymuştur. 2. grup ise değerlendirme basamağında \%54.1, yaratma basamağında ise \%59,5'lik bir başarı yüzdesine sahiptir. Her iki grupta da bu durumun gözlenmesi, taksonominin son iki basamağının bulunduğu düzey hakkında bizlere ipuçları sunmaktadır. Yenilenmiş Bloom taksonomisi, bilgi boyutu (Kavramsal, Olgusal, Bilişötesi ve İşlemsel Bilgi) ve bilişsel süreç boyutu (Anlama, Hatırlama, Analiz Etme, Uygulama, Oluşturma, Değerlendirme) olmak üzere iki farklı nitelikten oluşmaktadır. Taksonomiler eğitimde sınıflandırma yapmak amacıyla kullanılmakla birlikte birincil olarak değerlendirme üzerine yoğunlaşmaktadır (Eke, 2015).

Dinleme eğitimi, önemli bir alan olmasına rağmen öğretmenlerin önem verdiği öncelikli alan değildir. Melanlığlu'na (2013) göre "dinleme ilk edinilen beceridir fakat en çok ihmal edilen dil becerisi de yine dinlemedir". Yapılan çalışmalara göre öğretmenler en çok okuma becerileri hedeflerine öncelik vermektedir. Dolayısıyla öğrenciler en çok okuma becerileri hedeflerini kazanabilmektedirler. Öğretmenlerin dinleme becerileriyle ilgili hedeflere daha az önem vermesiyle birlikte belirlenen hedefleri öğrencilerin daha alt düzeyde kazandıkları görülmüştür (Yücel, Akar ve Batur 2003).

Dinleme becerisini ve daha önemlisi dinlediğini anlama becerisini geliştirmede çeşitli etkinlikler kullanılabilir. Türkçe öğretmeni adaylarına verilen dinleme eğitiminde kullanılan yöntem ve etkinliklerin çeşitliliği, adayların öğretmenlik yaptığı esnada öğrencilerine sunacakları çeşitli etkinliklere temel hazırlayacaktır. Göçer ve Kurt'un (2020) da yaptığı literatür taramasında Türkçe öğretiminde Doğan (2007) ve Kurt (2008) tarafından gerçekleştirilen çalışmalar dışında radyo oyunlarının kullanıldığı bir çalışmaya rastlanmamıştır. Bu da çalışmamızın alana katkısını güçlendiren bir sonuçtur.

Radyo tiyatrosunu seslendiren sanatçıların diksiyonları standart Türkçeye uygun olduğundan, radyo tiyatroları dinleyicilere genellikle kaliteli bir dinleme deneyimi sunar. "Her duyulan dinlenilmez, dinlenilenlerse her zaman anlaşılmaz. Buna konuşma hızıyla dinleme hızı arasındaki fark sebep olabilir" (Emiroğlu ve Pınar, 2013). Kaliteli bir radyo tiyatrosunda prozodik unsurlar doğru ve yerinde kullanıldığından dinleme eğitiminde radyo tiyatrolarının kullanımı iyi bir eğitsel araç olacaktır. Göçer ve Kurt da (2020) "teknolojinin ilerlemesine karşın radyonun varlığını sürdürmesi, radyo programlarının yapılması, çeşitli aplikasyonlarda radyo oyunlarının yayınlanması bu durumun göstergesidir. Buradan hareketle radyo oyunlarının dinleme ve konuşma etkinliği olarak kullanılmasını sağlamak ve radyo oyunlarını çeşitli platformlarda yayınlamak, ana dil eğitimine katkı sağlayacaktır” sonucuyla araştırmamızı olumlu yönde destekler niteliktedir.

Bu çalışmada elde edilen sonuçlara bakıldığında radyo tiyatrosu formatının dinleme eğitiminde kullanımı faydalı olacaktır; bununla birlikte bu araştırmanın farklı değişkenler, farklı yöntem ve veri toplama araçlarıyla da yapılmasının alana katkı sağlayacağı düşünülmektedir.

\section{KAYNAKÇA}

Aktaş, E. (2017). Öğretmen adaylarının farklı metin türlerine yönelik soru sorma becerilerinin yenilenmiş Bloom taksonomisine göre değerlendirilmesi. Electronic Turkish Studies, 12(25), 104.

Altunbay, M. (2012). Dil öğreniminde ve öğretiminde tiyatronun kullanımı ve tiyatronun temel dil becerilerine katkısı. Electronic Turkish Studies, 7(4), 747-760.

Başbay, M. (2008). Yenilenmiş taksonomiye göre düzenlenmiş öğretim tasarımı dersinde projeye dayalı öğretimin öğrenme ürünlerine etkisi. Ege Ĕ̈itim Dergisi, 8(1), 65-88.

Beall, M. L., Gill-Rosier, J., Tate, J., \& Matten, A. (2008). State of the context: Listening in education. The Intl. Journal of Listening, 22(2), 123-132.

Cankaya, Ö. (2011). Kaybolan bir program formatı: radyo tiyatrosu. Selçuk Illetişim, 6(4), 5-17. 
Cresswell, John W. (2019). Eğitim araştırmaları: nicel ve nitel araştırmanın planlanması, yürütülmesi ve değerlendirilmesi. İstanbul, Edam Yayınları, 414.

Doğan, S. (2007). Türkiye'de değişen radyo dinleme alışkanlı̆̆l ve özel radyolarda radyo tiyatrosu. (Yayımlanmamış yüksek lisans tezi). Marmara Üniversitesi Sosyal Bilimler Enstitüsü, İstanbul.

Eke, C. (2015). Dalgalar ünitesindeki kazanımların yenilenmiş bloom taksonomisine göre incelenmesi. Ĕ̆itim ve Ö̆̆retim Araştırmaları Dergisi. 345-353.

Emiroğlu, S., \& Pınar, F. N. (2013). Dinleme becerisinin diğer beceri alanları ile ilişkisi. Turkish Studies, 8(4), 769-782.

Göçer, A., \& Kurt, A. (2020). Sözlü iletişim becerilerinin gelişiminde radyo oyunlarının kullanımı üzerine kuramsal bir çalışma. Avrasya Dil Eğitimi ve Araştırmaları Dergisi, 4(2), 50-67.

Hand, R. J., \& Traynor, M. (2011). The radio drama handbook: Audio drama in context and practice. A\&C Black, 16.

Harmer, J. (2001). The practice of English language teaching. (3rd Ed.) Essex: Longman, 228-234.

Jensen, A. P. (2008). Multimodal literacy and theater education. Arts Education Policy Review, 109(5), 19-28.

Karabay, A. (2010). Kubaşık öğrenme etkinliklerinin ilköğretim beşinci sınıf Türkçe dersinde öğrencilerin dinleme ve konuşma becerileri üzerindeki etkileri. Çukurova Üniversitesi Sosyal Bilimler Enstitüsü, Adana.

Kurt, B. (2008). Çocuk edebiyatı ürünlerinin temel dil becerisi olarak dinlemenin gelişimine etkisi. Yüksek Lisans Tezi. Gazi Üniversitesi Eğitim Bilimleri Enstitüsü, Ankara.

Kars, N. (1993). Kavram ve içerik açısından radyo oyunları değerlendirmesi. Marmara İletişim Dergisi, 2(2), $273-302$.

Lynch, T., \& Mendelsohn, D. (2013). Listening. in an introduction to applied linguistics (pp. 190-206). Routledge.

MEB, (2019). Türkçe dersi ögrretim programı (İlkokul ve Ortaokul 1, 2, 3, 4, 5, 6, 7, 8.sınıflar), Ankara: Talim ve Terbiye Kurulu Başkanlığgı, s. 8-9.

Melanlığlu, D. (2013). Ortaokuldaki dinleme eğitiminin niteliğine ilişsin fenomografik bir araştırma/A phenomenological study on the quality of listening education at middle schools. Okuma Yazma Eğitimi Araştırmaları, 1(1), 34-44.

Özbay, M.(2001). Türkçe öğretiminde dinleme becerisini geliştirme yolları. Türk Dili Dergisi, S. 589, 9-15.

Renukadevi, D. (2014). The role of listening in language acquisition; the challenges \& strategies in teaching listening. International journal of education and information studies, 4(1), 59-63.

Schunk, D. H. (2014). Öğrenme teorileri: Ĕ̆itimsel bir baklşla. Ankara: Nobel.

Tutkun, Ö. F. (2012). Bloom’un Yenilenmiş Taksonomisi Üzerine Genel Bir Bakış. Sakarya Üniversitesi Eğitim Bilimleri Enstitüsü, 2(1), 14-22.

Tutkun, Ö. F., \& Okay, S. (2012). Bloom'un yenilenmiş taksonomisi üzerine genel bir bakış. Sakarya University Journal of Education, 1(3), 14-22.

Yagang, F. (1993). Listening: problems and solutions. In English Teaching Forum (Vol. 31, No. 2, pp. 16-19). Teacher Development, Making the Right Movies.

Yıldız, A. B., \& Savaş, B. (2019). Ezop masallarının dinleme becerisine etkisi. The Effect of Aesop's Tales on Listening Skills, s. 187.

Yücel, C., Akar, C., \& Batur, Z. (2003). Öğretmenlerin ilköğretim 8. sınıf Türkçe programında yer alan anlama becerileri ile ilgili hedeflere önem verme dereceleri ve ögrencilerin hedefleri kazanım düzeyleri. 89-102. 